\title{
The association of standardized patient educators (ASPE) gynecological teaching associate (GTA) and male urogenital teaching associate (MUTA) standards of best practice
}

\author{
Holly Hopkins ${ }^{1 *}$ (D) Chelsea Weaks², Tim Webster ${ }^{3}$ and Melih Elcin ${ }^{4}$
}

\begin{abstract}
Gynecological Teaching Associates (GTAs) and Male Urogenital Teaching Associates (MUTAs) instruct healthcare professional learners to perform accurate and respectful breast, speculum, bimanual vaginal, rectal, urogenital, and prostate examinations. During such sessions, the GTA/MUTA uses their own body to instruct while providing real-time feedback. While GTAs/MUTAs fall under the broader umbrella of Standardized Patient methodology, the specificity of their role indicates need for establishment of Standards of Best Practice (SOBP) for GTA/MUTA programs. On behalf of the Association of Standardized Patient Educators (ASPE), the Delphi process was utilized to reach international consensus identifying the Practices that comprise the ASPE GTA/MUTA SOBP. The original ASPE SOBP was used as the foundation for the iterative series of three surveys. Results were presented at the ASPE 2019 conference for additional feedback. Fifteen participants from four countries completed the Delphi process. Four of the original ASPE SOBP Domains were validated for GTA/MUTA programs: Safe Work Environment, Instructional Session Development, Training GTAs/MUTAs, and Program Management. Principles and Practices were shaped, and in some instances created, to best fit the distinct needs of GTA/MUTA programs. The ASPE GTA/MUTA SOBP apply to programs that engage GTAs/MUTAs in formative instructional sessions with learners. Programs that incorporate GTAs/MUTAs in simulation roles or in summative assessment are encouraged to reference the ASPE SOBP in conjunction with this document. The SOBP are aspirational and should be used to shape Practices within the program's local context. The ASPE GTA/MUTA SOBP will continue to evolve as our knowledge-base and practice develop.
\end{abstract}

Keywords: Gynecological teaching associate, Male urogenital teaching associate, Genitourinary training associate, Standardized patient, Professional patient, Standardized patient methodology, Physical examination instruction, Pelvic examination, Genitourinary examination, Rectal/prostate examination

\footnotetext{
* Correspondence: hhopkin3@emich.edu

'Eastern Michigan University School of Nursing, 311 Marshall Building, Ypsilanti, MI 48197, USA

Full list of author information is available at the end of the article
}

(c) The Author(s). 2021 Open Access This article is licensed under a Creative Commons Attribution 4.0 International License, which permits use, sharing, adaptation, distribution and reproduction in any medium or format, as long as you give appropriate credit to the original author(s) and the source, provide a link to the Creative Commons licence, and indicate if changes were made. The images or other third party material in this article are included in the article's Creative Commons licence, unless indicated otherwise in a credit line to the material. If material is not included in the article's Creative Commons licence and your intended use is not permitted by statutory regulation or exceeds the permitted use, you will need to obtain permission directly from the copyright holder. To view a copy of this licence, visit http://creativecommons.org/licenses/by/4.0/. The Creative Commons Public Domain Dedication waiver (http://creativecommons.org/publicdomain/zero/1.0/) applies to the data made available in this article, unless otherwise stated in a credit line to the data. 
The Association of Standardized Patient Educators (ASPE) published the ASPE Standards of Best Practice to identify guidelines for individuals and programs working with standardized patients (SPs). The ASPE SOBP identifies SPs as "a person trained to portray a patient in realistic and repeatable ways" [1]. Standardized patients may portray a patient, or they may be engaged in a purely instructional role. Gynecological Teaching Associates (GTAs) and Male Urogenital Teaching Associates (MUTAs), individuals that instruct learners to conduct breast, pelvic, rectal, urogenital, and prostate examinations are two examples of the application of SP methodology.

Historically, learners practiced pelvic examinations on plastic models, sex workers, anesthetized patients, and/or patients in clinic possibly alongside lectures, videos, and/ or observation [2]. In 1972, the term Gynecology Teaching Associate was developed based on SP methodology [3]. This role combined the "patient" with the "instructor" and emphasized both technical skills and interpersonal skills. In 1979, the first publications were released addressing the male-bodied corollary, MUTAs [4, 5]. GTA and MUTA programs have been documented in the United States, Canada [6, 7], Australia [8], Belgium [9], Sweden [10], the Netherlands [11], New Zealand [12], The United Kingdom [13], England [14], and Turkey [15].

Terminology and application of methodology varies among institutions and locations (e.g., Professional Patient, Clinical Teaching Associate). As with broader SP methodology [16, 17], this variance creates some challenges related to GTA/MUTA methodology, and there is need to create consensus on the role and identify associated standards of best practice. Because GTA/ MUTA interactions represent an application of SP methodology, it is ASPE's responsibility to identify such standards as the global organization focused on human simulation. ASPE currently hosts the GTA/MUTA Special Interest Group (SIG) which has been actively engaged in coordinating workshops, activities, and courses supporting this methodology. The ASPE GTA/MUTA SIG was created in 2010 as the first professional organization to address the needs of GTA/MUTA programs.

Consistent with the ASPE SOBP, the ASPE GTA/ MUTA SOBP "will provide a clear and definitive guide for all programs that" incorporate GTA/MUTA instructional sessions, with careful attention to making "these guidelines comprehensive and flexible enough to address the diversity of varying contexts" of GTA/MUTA programs [1]. The over-arching values of safety, quality, professionalism, accountability, and collaboration were identified within the ASPE SOBP [1] and apply to all SP Educators regardless of program type and/or context.

Because these standards are aspirational in nature, it is expected that institutions will be at varying degrees of implementation. The ASPE GTA/MUTA
SOBP specifically addresses instructional sessions, and the ASPE SOBP should be referenced when GTAs/ MUTAs are in the role of a SP or are otherwise incorporated into simulation activities and assessments. Following the ASPE GTA/MUTA SOBP will help [1] assure the physical and/or psychological safety of all participants in the session, [2] assure the effectiveness of the instructional session, and [3] decrease institutional legal risk.

\section{Terms related to GTA/MUTA methodology}

Gynecological Teaching Associate (GTA): "a female specifically trained to teach, assess, and provide feedback to learners about accurate pelvic, rectal and/or breast examination techniques. They also address the communication skills needed to provide a comfortable exam in a standardized manner, while using their own bodies [to instruct] in a supportive, non-threatening environment (ASPE)" [18].

Male Urogenital Teaching Associate (MUTA): "a male specifically trained to teach, assess, and provide feedback to learners about accurate urogenital and rectal examination techniques. They also address the communication skills needed to provide a comfortable exam in a standardized manner, while using their bodies [to instruct] in a supportive, non-threatening environment (ASPE)" [18].

$S P$ Educator (SPE): "used to refer to those who work to develop expertise in SP methodology and are responsible for training and/or administering [GTA/MUTA instructional sessions]. Some may be trainers who exclusively work with SPs[/GTAs/MUTAs], while some may be faculty or healthcare professionals who work with SPs[/GTAs/MUTAs] as part of their clinical and/or academic roles" [1]. The roles of GTA and MUTA represent an application of SP methodology, therefore individuals that train or administer GTA/MUTA program are specialized SP educators.

Instructional session: a period of time during which an instructor teaches learners relevant clinical content and safe assessment techniques. It is anticipated that a learner has received at least minimal preparation prior to an instructional session and the GTA/ MUTA builds their knowledge, competence, and confidence through hands-on practice with real-time feedback.

Learner: an individual who will be instructed by a GTA/MUTA. Learners are typically health professional students, practicing health professionals, or GTA/ MUTA trainees.

Participant: a person actively engaged in an instructional session including the GTA/MUTA, and learner(s).

Sensitive examinations: physical assessment of the breast, vulva, vagina, uterus, adnexa, penis, scrotum/ 
scrotal contents, inguinal region, rectum, and/or prostate.

Stakeholder: an individual impacted by GTA/MUTA sessions, which may include GTAs, MUTAs, staff, faculty, learners, and patients.

\section{Literature review}

A scoping review was undertaken separately to identify the implementation and utilization characteristics of GTA and MUTA programs [19]. Articles that addressed specific domains of the SOBP were identified. While each program will implement the domains in a way that fits their unique context, this evidence is provided to demonstrate examples of implementation strategies. Textbooks were not included within the scoping review, but are also a valuable resource regarding implementation strategies [20, 21].

\section{Process}

ASPE developed a subcommittee with the goal of using a modified Delphi process to reach international consensus identifying the Practices that comprise the ASPE GTA/ MUTA SOBP. Subcommittee members were selected based on demonstration of leadership within the ASPE GTA/MUTA SIG or active ASPE participation with experience in a GTA/MUTA program. The Eastern Michigan University granted Exempt status, UHRSC-FY18-19-65.

\section{Delphi process}

The Delphi Process was originally developed in the 1950's as a method of predicting future trends by building consensus among experts. "Delphi may be characterized as a method for structuring a group communication process so that the process is effective in allowing a group of individuals, as a whole, to deal with a complex problem" [22]. Implementation of the Delphi Method typically includes structured group communication, anonymous responses, and assessment of views at multiple time stamps. There is broad variation in how the Delphi Method is utilized [23] and evidence to support various aspects continues to develop. While the rigorous process of repeated responses and assessment can result in participant attrition, the Delphi process features key advantages, particularly surmounting geographical limitations among participants and the elimination of the influence of strong personalities and personal agendas [24, 25].

\section{Panelist recruitment}

Subcommittee members (the authors of this publication) identified individuals with expertise in GTA/MUTA methodology throughout the world using the following resources: known ASPE members/contacts, authors who published on GTA/MUTA methodology, and GTA/ MUTA programs with an online presence. Understanding that ASPE is an international organization with a large membership base from the United States, fifteen individuals from Australia, Belgium, New Zealand, Pakistan, Sweden, The Netherlands, the United Kingdom, and Canada were specifically invited to enhance international participation. Email invitations were additionally sent to the ASPE List-serve and the ASPE GTA/MUTA SIG List-serve. The invitation addressed the goals, the modified Delphi process, anticipated timeline, and inclusion criteria as listed:

- Must have at least 3 years of experience within a GTA and/or MUTA program

$\bigcirc$ Where GTAs and MUTAs instruct independently (as opposed to acting as models)

$O$ In one or more of the following roles:

- GTA or MUTA (instructing learners), and/or

- GTA/MUTA educator/trainer (instructing GTAs/MUTAs), and/or

- GTA/MUTA program administrator.

- Fluent in English (written)

- Currently affiliated with GTA/MUTA organization or network

- No conflict of interest

While the SOBP are directed at the program level (educators, trainers, and administrators), GTAs/MUTAs were included to represent their distinct and valuable perspective. Interested individuals emailed the Subcommittee to express interest and verify how they meet the inclusion criteria. To promote diversity, no more than one individual was to be confirmed to participate from each individual program. To ensure all stakeholders were represented, a balance of GTAs/MUTAs, GTA/ MUTA educators/trainers, and GTA/MUTA administrators were selected.

There is no standardized number of panelists to include in a Delphi process, but rather researchers must identify the number that best fits the breadth and depth of their topic [26]. The intent was for at least fifteen individuals to complete the Delphi process. The selected panelists remained confidential throughout the survey process to reduce bias.

\section{Survey completion}

Using the ASPE SOBP as a framework, panelists completed three iterative rounds of surveys within Survey Monkey, Inc. [27]. The initial survey asked panelists to [1] rate each ASPE SOBP Practice as it pertains to GTA/MUTA programs on a 5-point scale and to provide rationale for their rating as they deem necessary then [2] brainstorm as many Practices as possible that are important to GTA/ MUTA programs but were not addressed within the original ASPE SOBP. Pre-testing of the survey occurred during a workshop at the 2018 ASPE conference. 
After the initial survey, the Subcommittee consolidated the qualitative responses into the list of Practices. Identical items were removed and revisions were made only for clarity and grammar, but not for content. The consolidated list was combined with the ASPE SOBP for the second survey. The second and third surveys included only the rating of the Practices on a 5-point scale (Not Applicable, Somewhat Important, Important, Very Important, Critically Important) and rationale for their rating.

Rationale provided by panelists was summarized and provided alongside the mean and standard deviation at the introduction to the second and third surveys [28]. Rationale that was opinion-based (eg., "this is how we do that at my particular organization"), as opposed to causal (eg., a reflection on the universal importance of bodily autonomy), was not considered when developing the summary $[28,29]$.

Each survey was available for 2 weeks. Reminder emails were sent to panelists 10 days after each survey was released. Only panelists that completed the prior survey round were invited to participate in the following survey round. An email was sent to individuals that dropped out to explore changes that would have encouraged participation.

\section{Defining consensus}

After each survey, the Subcommittee conducted descriptive statistics using SPSS [30] on each item. Consensus was defined as a mean of 3.8 (on a 5point scale) with no participant rating an item as "Not Applicable". There is no evidence-based definition of consensus due to variance in topics and groups undertaking the Delphi process, however a systematic review assessing the quality of Delphi Process reporting indicated that, among studies providing a definition of consensus, $75 \%$ was the median threshold used [23]. When an item reached consensus, it was removed from further surveys but retained in the list of Practices, statistics, and rationale provided between each survey. The Delphi process was to end when consensus was reached on all items or after three survey rounds.

Upon completion, the authors presented the ASPE GTA/MUTA SOBP at the ASPE 2019 Annual Conference to obtain feedback. All conference attendees were invited to participate in a workshop that included presentation of the survey results and the opportunity to provide feedback. Workshop attendees were divided into small groups to provide written feedback. Feedback was evaluated and incorporated into the final document. The ASPE Executive Committee approved the final document.

\section{Results}

Twenty-one of the 26 interested individuals were selected for participation (Tables 1 and 2). While GTAs/MUTAs were qualified to participate, only one individual without educator/trainer or program administration experience expressed interest. Statistics and summarized feedback are available in the Online Supplementary File.

\section{Domains}

The Practices included within this document met statistical consensus for applicability to GTA/MUTA programs during the modified Delphi process; minor alterations were made to consensus-supported Practices to enhance clarity based on feedback as detailed above. Lack of inclusion of a Domain, Principle, or Practice included within the original ASPE SOBP does not negate the relevance of that item, but rather does [1] identify areas of future research and [2] highlight the need to consult the ASPE SOBP [1] when combining simulation or SP activities within a GTA/ MUTA practices. Where appropriate, numbering of the Practices has been retained from the original ASPE SOBP [1] to maintain compatibility; although this results in gaps in the numbering of Practices within this document, it allows for effective comparison with the original ASPE SOBP document. Practices that have been omitted from this document will be listed in the introduction for each Domain. There are areas where Practices are similar, but were not combined to ensure the nuance was appropriately conveyed to the reader.

\section{Domain 1: safe work environment}

Physical and psychological safety is critical in all working and learning environments, but it is especially critical when instructing learners to conduct sensitive examinations as GTAs/MUTAs do. This is an unique context for interaction with another person's body and it may trigger a variety of responses for both the GTA/MUTA [31-34]; and/or learner [35-40]. Physical and psychological safety are essential for all participants, and ensuring the bodily autonomy of the GTA/MUTA and learner(s) is an

Table 1 Survey Completion

\begin{tabular}{ll}
\hline Interested & 26 \\
Qualified & 25 \\
Invited & 21 \\
Completed Consent & 19 \\
Completed Round 1 & 16 \\
Completed Round 2 & 15 \\
Completed Round 3 & 15 \\
\hline
\end{tabular}


Table 2 Panelists

\begin{tabular}{|c|c|c|c|c|c|}
\hline \multirow[t]{2}{*}{ Participant } & \multirow[t]{2}{*}{ Institution } & \multirow[t]{2}{*}{ Country } & \multicolumn{3}{|c|}{ Experience in Role(s) } \\
\hline & & & GTA/MUTA & Educator/Trainer & $\begin{array}{l}\text { Program } \\
\text { Administrator }\end{array}$ \\
\hline Amy Allen & Emory University & USA & $x$ & $x$ & $x$ \\
\hline Kristen Benson & Multiple in Chicago & USA & $x$ & $x$ & $x$ \\
\hline Carrie Bohnert & University of Louisville & USA & & & $x$ \\
\hline Richard Claflin & Clinical Practice Resources for Training and Education & USA & $x$ & $x$ & $x$ \\
\hline John Darrow & East Carolina University & USA & $x$ & $x$ & $x$ \\
\hline Cathelijne de Ruyter & Maastricht University & The Netherlands & & $x$ & $x$ \\
\hline Valerie Fulmer & University of Pittsburgh & USA & & $x$ & $x$ \\
\hline Holly Hopkins & Eastern Michigan University & USA & $x$ & $x$ & $x$ \\
\hline Hal Kerbes & University of Calgary & Canada & $x$ & $x$ & $x$ \\
\hline Scott Lynch-Giddings & Midwestern University & USA & $x$ & $x$ & $x$ \\
\hline Lynn McBain & University of Otago & New Zealand & & & $x$ \\
\hline Jenny Murphy & University of Michigan & USA & $x$ & $x$ & $x$ \\
\hline Chelsea Weaks & Eastern Virginia Medical School & USA & $x$ & $x$ & \\
\hline Tim Webster & University of Winnipeg & Canada & $x$ & $x$ & $x$ \\
\hline Rose Zaeske & Johns Hopkins University & USA & $x$ & $x$ & $x$ \\
\hline
\end{tabular}

effective way to facilitate this. Within each unique program, GTA/MUTA input is beneficial regarding all Practices, but in order to reduce risk of personal compromise to health or safety, the SP educator should define reasonable limits. "It is important for the GTAs[/MUTAs] to provide an opinion on how many exams are comfortable for them but within limits. I am concerned that monetary gains may cause some men/women to offer to do more exams than are safe or comfortable. I believe it is the SP educators' job to put a reasonable limit on the number of exams" (Panelist).

"For the community of SP educators, there are three distinct principles related to creating a safe work environment: safe work practices, confidentiality, and respect" [1].

\begin{tabular}{|c|c|}
\hline Principle & Practice \\
\hline $\begin{array}{l}1.1 \text { Safe Work } \\
\text { Practices }\end{array}$ & $\begin{array}{l}\text { 1.1.1 Ensure safe working conditions in the design of the } \\
\text { activity (e.g., number of sessions; number of } \\
\text { examinations; number of breaks; and physical, cognitive, } \\
\text { and psychological challenges in the instructional } \\
\text { session). } \\
\text { 1.1.2 Anticipate and recognize potential occupational } \\
\text { hazards, including threats to GTA/MUTA safety and } \\
\text { bodily autonomy in the environment (e.g., allergenic } \\
\text { substances, exposure to sharps, air quality, live } \\
\text { defibrillators). } \\
\text { 1.1.3 Screen GTAs/MUTAs to ensure that they are } \\
\text { appropriate for the role (e.g., no conflict of interest, no } \\
\text { compromising of their or their learner's psychological } \\
\text { or physical safety). }\end{array}$ \\
\hline
\end{tabular}

(Continued)

\begin{tabular}{ll}
\hline Principle & Practice \\
\hline 1.1.4 Allow GTAs/MUTAs to decline involvement in any
\end{tabular}
activity or instructional session if they feel it is not appropriate or comfortable for them to participate (e.g., events with additional content, working during their menstrual cycle, traveling for events).

1.1.5 Brief GTAs/MUTAs so they are clear about the guidelines and parameters of an instructional session. 1.1.6 Provide GTAs/MUTAs with strategies to mitigate potential adverse effects of instructional sessions and prevent physical injury, psychological harm, or fatigue. 1.1.7 Inform GTAs/MUTAs and stakeholders about the criteria and processes for terminating an instructional session if they deem it harmful for themselves or a participant.

1.1.8 Create a process for debriefing with students and/or GTAs/MUTAs.

1.1.9 Monitor for and respond to GTAs/MUTAs who have experienced adverse effects from participation in an activity.

1.1.10 Provide a process for GTAs/MUTAs and stakeholders to report adverse effects from participation in a GTA/MUTA activity (e.g., documentation and action steps to resolve the situation).

1.1.11 Support GTAs/MUTAs who act in accordance with delineated program expectations if a complaint is made about them.

1.1.12 Manage stakeholder expectations of a GTA's/ MUTA's possibilities and limitations.

1.1.13 Work with stakeholders to clearly define the expected scope of GTA/MUTA involvement in work assignments.

1.1.14 Define and provide clear limitations regarding the scope of skills to be covered in an instructional session (e.g., maximum number of exams per day, exam techniques that must be included in each session, exam techniques that may be instructed but not practiced with a GTA/MUTA). 


\begin{tabular}{|c|c|}
\hline Principle & Practice \\
\hline & $\begin{array}{l}\text { 1.1.15 Reinforce techniques to reduce infection risk to } \\
\text { self and others related to sensitive examinations (e.g., } \\
\text { proper handling of clean and contaminated } \\
\text { equipment, hand hygiene, toileting). } \\
\text { 1.1.16 Ensure acknowledgement of learners that they } \\
\text { are aware of the nature of the instructional session } \\
\text { prior to entering the room. }\end{array}$ \\
\hline $\begin{array}{l}1.2 \\
\text { Confidentiality }\end{array}$ & $\begin{array}{l}\text { 1.2.1 Understand the specific principles of } \\
\text { confidentiality that apply to all aspects of each } \\
\text { instructional session. } \\
\text { 1.2.2 Ensure that stakeholders understand and } \\
\text { maintain the principles of confidentiality related to a } \\
\text { specific instructional session. } \\
\text { 1.2.3 Protect the privacy of the personal information of } \\
\text { all stakeholders, including that which may be revealed } \\
\text { within an instructional session. } \\
\text { 1.2.4 Maintain instructor and learner confidentiality by } \\
\text { protecting the privacy of any voice or video recording } \\
\text { related to a GTAMUTA instructional session. }\end{array}$ \\
\hline 1.3 Respect & $\begin{array}{l}\text { 1.3.1 Respect GTA's/MUTA's self-identified boundaries } \\
\text { (e.g., modesty, limits to physical touch, impact on } \\
\text { person). } \\
\text { 1.3.2 Provide GTAs/MUTAs with adequate information } \\
\text { so that they can make informed decisions about } \\
\text { participation in work assignments. } \\
\text { 1.3.3 Ensure that GTAs/MUTAs understand if and how } \\
\text { they are being compensated before accepting work } \\
\text { (e.g., may include payment for training and work } \\
\text { time, travel expenses, food vouchers, gift cards). }\end{array}$ \\
\hline
\end{tabular}

\section{Domain 2: instructional session development}

While the ASPE SOBP [1] Domain 2 focused on Case Development, GTAs/MUTAs primarily participate in instructional sessions, as opposed to portraying cases, indicating the need for a shift in terminology.

Many GTA/MUTA programs exist within broader SP programs or simulation centers which have a defined learning theory, feedback style, debriefing style, etc. To the extent possible, those interaction patterns should be extended to GTA/MUTA instructional sessions to provide clear support and intent for the sessions [41-44]. "The trainee should understand and expect when, where, and how feedback will be given. Feedback that comes unexpectedly, especially if it is negative, almost always is met by an emotional reaction impeding the processing of the information" [42]. Regardless of learning theory being utilized, the development of the materials to support an instructional session should be intentional.

As highlighted in the ASPE SOBP, the development of materials for instructional sessions is an iterative process of creation and refinement [1]. This is necessary to best serve the program and reflect the needs of all stakeholders. The majority of GTA/MUTA programs work with GTAs/MUTAs for formative instructional sessions; these standards reflect the need for a supportive environment that incorporates ongoing feedback from a skilled educator to support refinement of the skills being practiced [44]. If GTAs/MUTAs will be involved in summative evaluation and/or simulation, the ASPE SOBP [1] should be referenced for additional Practices that may be relevant: 2.2.9, 2.2.10, and 2.2.11.

\begin{tabular}{ll}
\hline Principle & Practice \\
\hline 2.1 Preparation & 2.1 .1 Ensure that instructional materials align \\
& with measurable learning objectives. \\
& 2.1 .2 Identify and engage relevant subject \\
& matter experts to assist in the creation of \\
& materials. \\
& 2.1 .3 Ensure that instructional protocols are \\
& based on up-to-date clinical practice guide- \\
& lines, are based on authentic problems, and \\
& respect the individuals involved in or dis- \\
& cussed during an instructional session to avoid \\
& bias, or stereotyping marginalized populations. \\
& 2.1 .4 Ensure that development of training \\
& materials allows sufficient time to draft, \\
& review, and edit materials prior to \\
& implementation. \\
& 2.1 .5 Ensure that changes arising from piloting \\
& processes are addressed prior to \\
& implementation of the training materials. \\
& Ensure instructional session components \\
include the following when appropriate: \\
\\
2.2 .1 Clear goals and objectives that can be \\
addressed. \\
2.2 .2 Goals and objectives that specify the \\
intended level of learners. \\
\\
2.2 .3 Instructional design that meets the \\
purpose. \\
\\
2.2 .4 Instructional design that is repeatable. \\
& 2.2 .5 Information for GTAs/MUTAs (e.g., \\
& description of physical examination \\
& techniques, cues). \\
& 2.2 .6 Training resources (e.g., equipment, \\
& videos, task trainers). \\
& 2.2 .7 Guidelines for providing feedback to \\
& learners. \\
& 2.2 .8 Briefing instructions, time frames, \\
& instructions to learners. \\
& \\
Components & Instructional Session
\end{tabular}

\section{Domain 3: GTA/MUTA training}

Training may be accomplished in a variety of ways, depending on the program goals. Training curriculum should be designed in a manner consistent with the learning theories and norms of the broader SP program or simulation center, as appropriate. The objectives of the instructional session will determine the extent of the training necessary regarding knowledge of physical examination techniques and effective provision of feedback to facilitate learner confidence and competence.

GTAs/MUTAs that will provide feedback on physical examination techniques should receive training that includes a physical exam from a provider or other trained individual so that they can characterize the sensations and learn to guide learners to that goal [44]. GTAs/MUTAs should also learn the characteristics of their own body, and the particular findings that a learner will or should experience while examining their body. Individual programs should determine any restrictions, if 
necessary, regarding the anatomy and physiology requirements for GTAs/MUTAs to ensure that learning outcomes may be achieved during instructional sessions.

The second primary component of GTA/MUTA training involves effective and expected provision of feedback. Provision of summative feedback is clearer if the instructor understands the expected outcome: either the learner completed the task appropriately or did not. Provision of formative feedback, however, involves clarification of goals, engaging the learner in self-assessment and dialog, providing instruction on how to modify the performance, and facilitating "opportunities to close the gap between current and desired performance" all while supporting the learner's self-confidence ([45], p. 205).

The majority of GTA/MUTA programs utilize GTAs/ MUTAs for formative instructional sessions. If GTAs/ MUTAs will be involved in summative evaluation and/ or simulation, the ASPE SOBP [1] should be referenced for additional Practices that may be relevant: 3.2.8, 3.2.10, 3.3.6, 3.4.1-3.4.8.

\begin{tabular}{|c|c|}
\hline Principle & Practice \\
\hline $\begin{array}{l}\text { 3.1 Preparation for } \\
\text { Training }\end{array}$ & $\begin{array}{l}\text { 3.1.1 Review the purpose, objectives and outcomes, } \\
\text { logistics, and instructional materials of the activity. } \\
\text { 3.1.2 Address one's own knowledge gaps, if any. } \\
\text { 3.1.3 Create a training plan that is responsive to } \\
\text { the context and format of each activity } \\
\text { (e.g., group/peer training for standardization, } \\
\text { video review, practice with simulation equipment). } \\
\text { 3.1.4 Gather training resources to supplement } \\
\text { training. } \\
\text { 3.1.5 Gather administration documents and } \\
\text { special instructions. }\end{array}$ \\
\hline $\begin{array}{l}\text { 3.2 Training for } \\
\text { Instructional } \\
\text { Session }\end{array}$ & $\begin{array}{l}\text { 3.2.1 Review with GTAs/MUTAs the key objectives, } \\
\text { responsibilities, context (e.g., formative, summative, } \\
\text { level of learner, placement in curriculum) and format } \\
\text { (e.g., length of encounter, type of encounter) of each } \\
\text { activity. } \\
\text { 3.2.2 Engage GTAs/MUTAs in discussion and practice } \\
\text { of instructional session features (e.g., techniques, } \\
\text { behaviors, expectations, and guidance to provide). } \\
\text { 3.2.3 Provide GTA/MUTAs with strategies to deal } \\
\text { with unanticipated learner questions, behaviors, } \\
\text { and/or actions. } \\
\text { 3.2.4 Ensure consistency and accuracy of instructional } \\
\text { session of individual GTAs/MUTAs, and among } \\
\text { groups of GTAs/MUTAs with the same role. } \\
\text { 3.2.5 Ensure GTA/MUTA readiness for the } \\
\text { instructional session through repeated practice and } \\
\text { targeted feedback. } \\
\text { 3.2.6 Provide periodic refresher or re-calibration } \\
\text { training, even if the instructional session does not } \\
\text { change. } \\
\text { 3.2.7 Provide training on procedural skills (e.g., Pap } \\
\text { collection) and equipment for training (e.g., task } \\
\text { trainers) if utilized during instructional sessions. } \\
\text { 3.2.9 Review current topics that are applicable to } \\
\text { and/or potentially impact instructional sessions } \\
\text { (e.g., consent, sexual violence, communication). } \\
\text { 3.2.11 Educate regarding and reinforce techniques } \\
\text { to reduce risk of physical and psychological harm }\end{array}$ \\
\hline
\end{tabular}

(Continued)

\begin{tabular}{|c|c|}
\hline Principle & Practice \\
\hline & $\begin{array}{l}\text { to GTA/MUTA and learner (e.g., appropriate touch, } \\
\text { appropriate pressure, consent, terminology, } \\
\text { communication techniques). } \\
\text { 3.2.12 Provide GTAs/MUTAs with the opportunity } \\
\text { to demonstrate proficiency in examination } \\
\text { maneuvers that they will be instructing. } \\
\text { 3.2.13 Ensure pre-session resources are provided to } \\
\text { learners to prepare them for the instructional ses- } \\
\text { sions (e.g., institution-prepared materials, textbook } \\
\text { reading assignments related to gynecological and } \\
\text { urological exams). }\end{array}$ \\
\hline $\begin{array}{l}3.3 \text { Training for } \\
\text { Feedback }\end{array}$ & $\begin{array}{l}\text { 3.3.1 Review with GTAs/MUTAs the fundamental } \\
\text { principles of feedback as an instructional } \\
\text { methodology to be applied to the planned activity } \\
\text { 3.3.2 Inform GTAs/MUTAs of the feedback } \\
\text { objectives and level of the learners with whom } \\
\text { they will be working. } \\
\text { 3.3.3 Inform GTAs/MUTAs of the feedback logistics } \\
\text { and setting (e.g., individual feedback with learner, } \\
\text { small group feedback, written feedback, intended } \\
\text { structure). } \\
\text { 3.3.4 Train GTAs/MUTAs to use their observations, } \\
\text { bodily sensations, and knowledge to provide } \\
\text { feedback on observable, modifiable behaviors in } \\
\text { learners. } \\
\text { 3.3.5 Ensure GTA/MUTA readiness through } \\
\text { repeated practice and targeted feedback. } \\
\text { 3.3.7 Train GTAs/MUTAs to recognize and respond } \\
\text { to a learner that is having a negative experience } \\
\text { during the instructional session (e.g. history of } \\
\text { violence, discomfort with anatomy), with the } \\
\text { intention of ensuring a safe, nontraumatic learning } \\
\text { environment. }\end{array}$ \\
\hline $\begin{array}{l}\text { 3.5 Reflection on } \\
\text { the Training } \\
\text { Process }\end{array}$ & $\begin{array}{l}\text { 3.5.1 Reflect on one's own training practices for } \\
\text { future improvement (e.g., evaluation forms, } \\
\text { debriefing, video review). }\end{array}$ \\
\hline
\end{tabular}

\section{Domain 4: program management}

Many GTA/MUTA programs exist within broader SP and/ or simulation programs but regardless of their institutional affiliation or location the broad program should follow standard business processes and procedures. This includes "creating financial management, business, and strategic plans" for the broad organization and (as applicable) specific programs [1]. The purpose for the GTA/MUTA instructional session should be determined, and should be consistent throughout. "[GTA/MUTA] programs provide a trained expert/educator in [GTA/MUTA] methodology, a trained cohort of [GTAs/MUTAs], a collaborative expertise in using [GTA/MUTA] methodology, and processes that administer [GTA/MUTA] services efficiently and cost effectively. Regardless of size, [GTA/MUTA] programs are responsible for quality management practices, including quality planning, quality assurance, quality control, and quality improvement (see INACSL Standard: Professional Integrity [8]). Clearly stated policies and procedures allow a [GTA/MUTA] program to demonstrate that it meets ethical, humanistic, professional, legislated, institutional, and practice standards for screening, recruiting, managing, 
and monitoring [GTAs/MUTAs] and other staff working with them" [1].

The ASPE SOBP [1] should be referenced for additional Practices as appropriate: 4.3.2, 4.3.3, 4.3.4, 4.4.1, and 4.6.1.

\begin{tabular}{ll}
\hline Principle & Practice \\
\hline 4.1 Purpose & 4.1.1 Articulate a mission statement for the program. \\
& 4.1.2 Develop program goals. \\
& 4.1 .3 Identify measurable objectives for each goal \\
& (where applicable). \\
& 4.2.1 Possess depth of knowledge in GTA/MUTA \\
& methodology. \\
& 4.2.2 Advocate for the integration of GTA/MUTA \\
& methodology into the curriculum where \\
& appropriate. \\
& 4.2.3 Identify when GTAs/MUTAs should be \\
& incorporated into an instructional session. \\
& 4.2.4 Collaborate with subject matter experts to \\
design GTA/MUTA instructional sessions and & materials. \\
& 4.2.5 Train GTAs/MUTAs according to the parameters \\
of the instructional session.
\end{tabular}

4.3 Policies and Procedures

4.4 Records Management

4.5 Team Management
4.3.1 Develop and document policies to guide program activities.

4.3.4 Ensure policies and procedures are kept current and accessible.

4.3.5 Distribute policies and procedures to relevant stakeholders.

4.3.6 Develop and document policies that protect ethnicity, skin color, national origin, religion, body habitus, sex, sexual orientation, gender identity, and/or gender presentation).

4.3.7 Develop and document policies for termination of an instructional session and/or case related to GTA/MUTA or learner concern. 4.3.8 Develop and document policies regarding various bodily processes that may impact and/or occur during instructional sessions and/or scenarios (e.g., discharge, vaginal bleeding, erection, passing gas or stool, infection). 4.3.9 Develop a policy or protocol for instruction of procedural skills during GTA/MUTA sessions (e.g., collection of samples).

4.3.10 Develop a policy or protocol for injury reporting and medical management if an injury occurs.

4.4.2 Ensure that policies are in place for sharing and archiving the materials of instructional sessions. 4.4.3 Develop and document methods for securely storing, archiving, and destroying confidential data (e.g., GTA/MUTA records, learner data, audio/video data, consent forms, release forms).

4.5.1 Consult with legal, financial, and human resources experts to ensure that status of GTAs/ MUTAs (e.g., employee, independent contractor, volunteer) and compensation structure (if applicable) comply with institutional requirements. 4.5.2 Develop processes to identify, screen, interview, select, debrief, and maintain GTAs/MUTAs and staff. 4.5.3 Recruit and maintain a cohort of GTAs/MUTAs that is inclusive and diverse.

4.5.4 Establish policies and procedures for the groups from discrimination (e.g., ability, age, race,

\begin{tabular}{|c|c|}
\hline Principle & Practice \\
\hline & $\begin{array}{l}\text { psychological, physical, and environmental safety of } \\
\text { GTAs/MUTAs, learners, staff, and faculty. } \\
\text { 4.5.5 Advocate for ongoing professional } \\
\text { development opportunities for all staff, including } \\
\text { GTAs/MUTAs. }\end{array}$ \\
\hline $\begin{array}{l}\text { 4.6 Quality } \\
\text { Management }\end{array}$ & $\begin{array}{l}\text { 4.6.2 Gather feedback regularly from GTAs/MUTAs, } \\
\text { learners, faculty, and other users regarding the } \\
\text { quality of services provided by the program. } \\
\text { 4.6.3 Analyze data and other feedback in a timely } \\
\text { manner. } \\
\text { 4.6.4 Implement changes for continuous } \\
\text { improvement. } \\
\text { 4.6.5 Inform stakeholders of changes made based } \\
\text { on their feedback. }\end{array}$ \\
\hline
\end{tabular}

\section{Discussion}

Overall, the Practices within the first 4 Domains that were omitted reflected components related to SP simulation as opposed to GTA/MUTA instructional sessions. This indicates that the consensus building process was effective. Only one panelist was lost to attrition once the survey process began, indicating that the surveys were not too complex or timeconsuming.

Far more individuals expressed interest and were invited to participate than completed the process. Perspectives from 4 countries were ultimately represented although we aimed to have more global representation of panelists. While we can expect cultural differences reflected among GTA/MUTA programs in varying locations, a recent Scoping Review did not demonstrate consistent geographic variance in program specifics [19]. Although the Scoping Review indicates that it would not have significantly altered results, diversity should always be valued and encouraged. Future research should identify the degree of GTA/ MUTA program implementation throughout the world and explore geographic and cultural variance among existing GTA/MUTA programs.

Three members of the research team $(\mathrm{HH}, \mathrm{TW}$, and CW) also completed the surveys for the Delphi process. They did not have access to participant responses prior to completing the surveys themselves and so were unable to impart bias. The protocol defined that all feedback and responses would be generalized from survey responses, so there was no opportunity for the researchers to impart their own individual bias. Other panelists did not know that these individuals were also participating as panelists.

The Practices within Domain 1, Safe Work Environment, reached consensus with ease. Panelists were very agreeable that safety is critical, however safety is infrequently addressed within the literature on GTA/ MUTA programs. Further research should explore how 
Table 3 Evidence Supporting the Domains

\begin{tabular}{|c|c|c|c|c|c|c|}
\hline & $\begin{array}{l}\text { Country } \\
\text { Represented }\end{array}$ & $\begin{array}{l}1 \\
\text { Safe Work } \\
\text { Environment }\end{array}$ & $\begin{array}{l}2 \\
\text { Case } \\
\text { Development }\end{array}$ & $\begin{array}{l}3 \\
\text { Training } \\
\text { SPs }\end{array}$ & $\begin{array}{l}4 \\
\text { Program } \\
\text { Management }\end{array}$ & $\begin{array}{l}5 \\
\text { Professional } \\
\text { Development }\end{array}$ \\
\hline Godkins, Duffy, Greenwood, \& Stanhope, 1974 [46] & USA & & $x$ & $x$ & $x$ & \\
\hline $\begin{array}{l}\text { Johnson, Brown, Stenchever, Gabert, Poulson, \& } \\
\text { Warenski, } 1975 \text { [47] }\end{array}$ & USA & & & $x$ & $x$ & \\
\hline Women's Community Health Center, Inc., 1975 [48] & USA & & & & $x$ & \\
\hline Hale \& Shiner, 1977 [49] & USA & & $x$ & $x$ & $x$ & \\
\hline Kretzschmar, 1978 [3] & USA & $x$ & $x$ & $x$ & $x$ & $x$ \\
\hline Livingstone \& Ostrow, 1978 [6] & Canada & & $x$ & $x$ & & \\
\hline Nelson, $1978[50]$ & USA & & & & $x$ & \\
\hline $\begin{array}{l}\text { Behrens, Barnes, Gerber, Albanese, Matthes, } \\
\text { Cangelosi, } 1979 \text { [4] }\end{array}$ & USA & & $x$ & & $x$ & \\
\hline Gerber, Matthes, Albanese, 1979 [5] & USA & & & & $x$ & \\
\hline Wheeler, Burke, Ling, 1981 [51] & USA & & $x$ & $x$ & $x$ & $x$ \\
\hline $\begin{array}{l}\text { Laube, Kretzschmar, Guenther, Lessner, } \\
\text { Guthrie, } 1982 \text { [52] }\end{array}$ & USA & & $x$ & $x$ & & \\
\hline Fang, Hillard, Lindsay, Underwood, 1984 [53] & USA & & $x$ & & & \\
\hline Beckmann, Sharf, Barzansky, Spellacy, 1986 [54] & USA & & $x$ & & & \\
\hline Hillard \& Fang, 1986 [55] & USA & & & & $x$ & \\
\hline Beckmann, Barzansky, Sharf, Meyers, 1988 [56] & USA & $x$ & & $x$ & $x$ & $x$ \\
\hline Beckmann \& Meyers, 1988 [31] & USA & $x$ & & & & \\
\hline Muggah \& Stateson, 1988 [57] & Canada & & & $x$ & & \\
\hline Nieman, Kelliher, Sachdeva, Cohen, 1994 [58] & USA & & $x$ & & & \\
\hline $\begin{array}{l}\text { Sachdeva, Wolfson, Blair, Gillum, Gracely, } \\
\text { Friedman, } 1997 \text { [59] }\end{array}$ & USA & & & & $x$ & \\
\hline $\begin{array}{l}\text { Costanza, Luckmann, Quirk, Clemow, White, } \\
\text { Stoddard, } 1999 \text { [60] }\end{array}$ & USA & & $x$ & $x$ & & \\
\hline Legro, Gnatuk, Kunselman, Cain, 1999 [61] & USA & & & $x$ & $x$ & \\
\hline Hendrickx, De Winter, Wyndaele, Tonks, 2003 [62] & Belgium & $x$ & & $x$ & $x$ & \\
\hline Carr \& Carmody, 2004 [63] & Australia & & & & $x$ & \\
\hline $\begin{array}{l}\text { Coleman, Stewart, Wilson, Cantrell, O'Sullivan, } \\
\text { Carthron, Wood, } 2004 \text { [64] }\end{array}$ & USA & & & $x$ & & \\
\hline $\begin{array}{l}\text { Hendrickx, de Winter, Wyndaele, Tjalma, Debaene, } \\
\text { Selleslags, Mast, Buytaert, Bossaert, } 2006 \text { [9] }\end{array}$ & Belgium & & & & $x$ & \\
\hline Siwe, Wijma, Stjernquist, Wijma, 2007 [65] & Sweden & & $x$ & $x$ & & \\
\hline $\begin{array}{l}\text { Boendermaker, Faber, Schultz, } \\
\text { Weijmar, } 2008 \text { [66] }\end{array}$ & The Netherlands & & $x$ & $x$ & & \\
\hline Robertson, Hegarty, O'Connor, \& Gunn, 2008 [8] & Australia & $x$ & $x$ & & $x$ & \\
\hline $\begin{array}{l}\text { Bokken, Linssen, Scherpbier, van der Vleuten, } \\
\text { Rethans, } 2009 \text { [67] }\end{array}$ & The Netherlands & & & $x$ & $x$ & \\
\hline Jha, Setna, Al-Hity, Quinton, Roberts, 2010 [68] & United Kingdom & & $x$ & & $x$ & \\
\hline Pradhan, Ebert, Brug, Swee, Ananth, 2010 [69] & USA & & & & $x$ & \\
\hline $\begin{array}{l}\text { Siebeck, Schwald, Frey, Röding, Stegmann, \& } \\
\text { Fischer, } 2011 \text { [70] }\end{array}$ & Germany & & & $x$ & & \\
\hline Seago, Ketchum, Willett, 2012 [71] & USA & & & & $x$ & \\
\hline Grankvist, Olofsson, Isaksson, 2014 [72] & Sweden & & $x$ & $x$ & & \\
\hline Nikendei, Diefenbacher, Köhl-Hackert, Lauber, & Germany & & $x$ & $x$ & $x$ & \\
\hline
\end{tabular}


Table 3 Evidence Supporting the Domains (Continued)

\begin{tabular}{|c|c|c|c|c|c|c|}
\hline & $\begin{array}{l}\text { Country } \\
\text { Represented }\end{array}$ & $\begin{array}{l}1 \\
\text { Safe Work } \\
\text { Environment }\end{array}$ & $\begin{array}{l}2 \\
\text { Case } \\
\text { Development }\end{array}$ & $\begin{array}{l}3 \\
\text { Training } \\
\text { SPs }\end{array}$ & $\begin{array}{l}4 \\
\text { Program } \\
\text { Management }\end{array}$ & $\begin{array}{l}5 \\
\text { Professional } \\
\text { Development }\end{array}$ \\
\hline McBain, Pullon, Garrett, Hoare, 2016 [12] & New Zealand & & $x$ & & $x$ & \\
\hline Sörensdotter and Siwe, 2016 [35] & Sweden & & & $x$ & & \\
\hline $\begin{array}{l}\text { Janjua, Smith, Chu, Raut, Malick, Gallos, } \\
\text { Singh, Irani, Gupta, Parle, Clark, } 2017 \text { [73] }\end{array}$ & United Kingdom & & $x$ & & & \\
\hline
\end{tabular}

Studies are presented in chronological order to demonstrate changes in focus over time

SP educators perceive safety and how GTAs/MUTAs experience safety within an instructional session and simulations. The research supporting Domains 2 (Instructional Session Development), 3 (Training GTAs/ MUTAs), and 4 (Program Management) is more robust, however the majority of publications are case reports detailing an individual program. Further research is indicated to demonstrate the components of effective instructional session development, strategies to optimize GTA/MUTA training, and analysis of how and whether GTA/MUTA program management is distinct from broader SP program management.

Per Lewis et al. [1], SP educators should seek professional development opportunities to further their expertise and reach. While statistical analysis only indicated consensus on Practice 5.3.2 within Domain 5, the original ASPE SOBP should be referenced by all SP educators for additional Practices that are relevant. Three of the studies addressing GTA/MUTA methodology address professional development (Table 3). Professional development is encouraged by the ASPE SOBP [1] and the Simulationist Code of Ethics [74], which both apply to all SP educators regardless of context. Additional research is indicated to determine methods for enhancing professionalization of the SP educator role, specifically engagement of GTA/MUTA methodology experts. Research should be conducted to determine whether individuals that administer GTA/MUTA programs and/or train GTAs/MUTAs identify as SP educators and whether there is a difference in perceived value that an organization places on these individuals.

There were comments within the survey responses expressing concern about the use of gendered terminology in relation to GTA/MUTA sessions. The Association of American Medical Colleges' [75] work towards inclusiveness and gender-neutral terminology is one step towards meeting that aim. Modifying terminology is beyond the scope of this project, but in the event that GTA/MUTA terminology does change in the future, this document will continue to apply to individuals and programs fulfilling the roles defined.

The ASPE GTA/MUTA SOBP demonstrates expert consensus regarding aspirational standards that all GTA/MUTA programs should aspire to uphold. These standards were designed to ensure safety, promote educational effectiveness, and reduce institutional risk. ASPE will periodically engage in rigorous methodology to ensure the GTA/MUTA SOBP continue to reflect expert consensus and growth of the roles of the SP educator and GTA/MUTA.

Abbreviations

ASPE: Association of Standardized Patient Educators; GTA: Gynecological Teaching Associate; MUTA: Male Urogenital Teaching Associate;

SOBP: Standards of Best Practice

\section{Supplementary Information}

The online version contains supplementary material available at https://doi. org/10.1186/s41077-021-00162-4.

Additional file 1. ASPE GTA MUTA SOBP Survey Results

\section{Acknowledgements}

Holly A. Gerzina, Cathy Smith, and Tonya M. Thompson were instrumental in adaptation of the Delphi Process to fit this project. This work was conducted on behalf of the Association of Standardized Patient Educators (ASPE). The authors wish to thank the anonymous reviewers whose comments greatly improved the quality of this paper.

\section{Authors' contributions}

$\mathrm{HH}$ developed the design of the study and applied for IRB approval with input from ME, TW, and CW. HH conducted the bulk of recruitment and email communication with participants. CW conducted primary analysis of the data from Domain 1, TW for Domain 2, HH for Domain 3, and ME for Domain 4 and 5. $\mathrm{HH}$ compiled the analysis for all Domains then all authors reviewed the analysis and discussed concerns, discrepancies, and potential revisions. All authors read and approved the final manuscript.

\section{Author's information}

$\mathrm{HH}$ is the Chair of the ASPE Standards of Practice Committee, the Past Chair of the ASPE GTA/MUTA Special Interest Group, and administers the GTA/ MUTA program at her home institution. She has been involved in GTA work for 18 years. ME initiated the first GTA program in Turkey in 2015. TW is the Chair of the ASPE GTA/MUTA Special Interest Group and administers the MUTA program at his home institution. He has been involved in MUTA work for 22 years. CW is the Vice Chair of the ASPE GTA/MUTA Special Interest Group and administers the GTA program at her home institution. She has been a GTA for 8 years.

\section{Funding}

Not applicable.

Availability of data and materials

A summary of data generated or analyzed during this study are included in a supplementary information file. The datasets analyzed during the current study are available from the corresponding author on reasonable request. 


\section{Declarations}

\section{Ethics approval and consent to participate}

The Eastern Michigan University granted Exempt status, UHRSC-FY18-19-65.

\section{Consent for publication}

Consent for publication was obtained through the informed consent process approved through IRB.

\section{Competing interests}

The authors declare that they have no competing interests.

\section{Author details}

'Eastern Michigan University School of Nursing, 311 Marshall Building Ypsilanti, MI 48197, USA. Eastern Virginia Medical School Sentara Center for Simulation and Immersive Learning, 651 Colley Avenue, Norfolk, VA 23501, USA. ${ }^{3}$ University of Manitoba Rady Faculty of Health Sciences, 250 Brodie Centre, 727 McDermot Avenue, Winnipeg, Manitoba R3E 3P5, Canada. ${ }^{4}$ Department of Medical Education and Informatics, Hacettepe University Faculty of Medicine, Sihhiye Campus, 06100 Ankara, Turkey.

\section{Received: 12 October 2020 Accepted: 17 February 2021}

\section{Published online: 21 June 2021}

\section{References}

1. Lewis K, Bohnert C, Gammon WL, Holzer H, Lyman L, Smith C, et al. The Association of Standardized Patient Educators (ASPE) standards of best practice (SOBP). Adv Simul. 2017;2:10.

2. Beckmann CRB, Spellacy WN, Yonke A, Barzansky B, Cunningham R. Initial instruction in the pelvic examination in the United States and Canada, 1983. Am J Obstet Gynecol. 1985;151(1):58-60.

3. Kretzschmar RM. Evolution of the gynecology teaching associate: an educational specialist. Am J Obstet Gynecol. 1978;131(367):367-72.

4. Behrens A, Barnes HV, Gerber WL, Albanese M, Matthes S, Cangelosi A. A model for teaching sophomore medical students the essentials of the male genital-rectal examination. J Med Educ. 1979;54:585-7.

5. Gerber W, Matthes S, Albanese M. A comparison of instructional techniques: internal-external vs external only. In: Eighteenth annual conference on research in medical education; 1979. p. 59-64.

6. Livingstone RA, Ostrow CN. Professional patient-instructors in the teaching of the pelvic examination. Am J Obstet Gynecol. 1978;132(1):64-7.

7. Nensi A, Chande N. A survey of digital rectal examination training in Canadian medical schools. Can J Gastroenterol. 2012;26(7):441-4.

8. Robertson K, Hegarty K, O'Connor V, Gunn J. Women teaching women's health: issues in the establishment of a clinical teaching associate program for the well woman check. Women Health. 2008:37(4):49-65 https://doi. org/10.1300/J013v37n4_05.

9. Hendrickx K, De Winter BY, Wyndaele J, Tjalma WAA, Debaene L, Selleslags $B$, et al. Intimate examination teaching with volunteers: implementation and assessment at the University of Antwerp. Patient Educ Couns. 2006;63:47-54 https://doi.org/10.1016/j.pec.2005.08.009.

10. Wänggren K, Jonassen AF, Andersson S, Pettersson G, Gemzell-Danielsson K Teaching pelvic examination technique using professional patients: a controlled study evaluating students' skills. Acta Obstet Gynecol. 2010;89: 1298-303 https://doi.org/10.3109/00016349.2010.501855.

11. Van Ravesteijn $H$, Hageraats $E$, Rethans J. Training of the gynaecological examination in the Netherlands. Med Teach. 2007;29:e93-9 https://doi.org/1 0.1080/01421590801287921.

12. McBain L, Pullon S, Garrett S, Hoare K. Genital examination training: assessing the effectiveness of an integrated female and male teaching programme. MBC Med Educ. 2016;16(1):299 https://doi.org/10.1186/s12909016-0822-y.

13. Janjua A, Smith P, Clark TJ. A cross-sectional study on teaching pelvic examination in medical schools in the UK (the COTES study). J Obstet Gynecol. 2018;38(4):521-5 https://doi.org/10.1080/01443615.2017.1363726.

14. Duffy JMK, Chequer S, Braddy A, Mylan S, Royuela A, Zamora J, et al. Educational effectiveness of gynaecological teaching associates: a multi-Centre randomised controlled trial. BJOJ. 2016;123:6 https://doi.org/10.1111/1471-0528.13824.

15. Sarmasoglu S, Dinc L, Elcin M, Tarakcioglu Celik GH, Polonko I. Success of the first gynecological teaching associate program in Turkey. Clin Simul Nurs. 2016;12(6):305-12.
16. Nestel D, Murphy P, Chianain LN, Gormley G. They're called what? BMJ Simul Technol Enhanced Learn Online First. https://doi.org/10.1136/ bmjstel-2020-000735.

17. Sanko JS, Schneidereith T, Cowperthwait A, Onello R. Findings from a human roles terminology survey: consensus or chaos? BMJ Simul Technol Enhanced Learn. 2020;6(3):158.

18. Lioce L. In: Loprieato J, Downing D, Chang TP, Robertson JM, Anderson M, Diaz DA, Spain AE, the Terminology and Concepts Working Group, editors. Healthcare simulation dictionary. 2nd ed. Rockville: Agency for Healthcare Research and Quality; 2020. https://doi.org/10.23970/simulationv2.

19. Hopkins H, Weaks C, Napier E. Implementation and utilization of gynecological teaching associate and male urogenital teaching associate programs: a scoping review. In review.

20. Gliva-McConvey G, Nicholas CF, Clark L, editors. Comprehensive healthcare simulation: implementing best practices in standardized patient methodology: Springer; 2020. ISBN: 978-3-030-42836-5

21. Nestel D, Bearman M, editors. Simulated patient methodology: theory, evidence, and practice: Wiley-Blackwell; 2014. ISBN: 978-1-118-76100-7

22. Linstone $H$, Turoff $M$. The delphi method: techniques and applications. Newark: New Jersey Institute of Technology; 2002.

23. Diamond IR, Grant RC, Feldman BM, Pencharz PB, Ling SC, Moore AM, et al. Defining consensus: a systematic review recommends methodologic criteria for reporting of Delphi studies. J Clin Epidemiol. 2014;67:401-9 https://doi. org/10.1016/j.jclinepi.2013.12.002.

24. Dalkey N, Helmer O. An experimental application of the delphi method to the use of experts. Santa Monica: The RAND Corporation; 1962. https:// www.rand.org/content/dam/rand/pubs/research_memoranda/2009/RM72 7.1.pdf. Accessed 24 Apr 2019

25. Iqpal S, Pipon-Young L. The Delphi method. Psychologist. 2009;2(7):598-601

26. Pare G, Cameron A, Poba-Nzaou P, Templier M. A systematic assessment of rigor in information systems ranking-type Delphi studies. Inf Manag. 2013; 50:207-17 https://doi.org/10.1016/j.im.2013.03.003.

27. Survey Monkey Inc. 2019. Available from: http://surveymonkey.com Accessed 15 May 2019.

28. Bolger F, Wright $G$. Improving the Delphi process: lessons learned from psychological research. Technol Forecasting Soc Change. 2011;78:1500-13 https://doi.org/10.1016/j.techfore.2011.07.007.

29. Bolger F, Stranieri A, Wright G, Yearwood J. Does the Delphi process lead to increased accuracy in group-based judgmental forecasts or does it simply induce consensus amongst judgmental forecasters? Technol Forecasting Soc Change. 2011;78:1671-90 https://doi.org/10.1016/j.techfore.2011.06.002.

30. Corp IBM. IBM statistics for Macintosh, version 26.0. Armonk: IBM Corp; 2019

31. Beckmann CBB, Meyers K. Mental and physical effects of being a Gynecologic Teaching Associate. J Reprod Med. 1988;33(1):22-4.

32. Nikendei C, Diefenbacher K, Kohl-Hackert N, Lauber H, Huber J, HerrmannWener A, et al. Digital rectal examination skills: first training experiences, the motives and attitudes of standardized patients. BMC Med Educ. 2015:15:7 https://doi.org/10.1186/s12909-015-0292-7.

33. Fairbank C, Reid K, Minzenmay K. Women's experiences of working as a clinical teaching associate teaching sensitive examinations: a qualitative study. Med Teach. 2015:37:47-52.

34. Siwe K, Wijma B, Bertero C. 'A stronger and clearer perception of self'. Women's experience of being professional patients in teaching the pelvic examination: a qualitative study. Gen Gynaecol. 2006;113:890-5 https://doi. org/10.1111/j.1471-0528.2006.02029.c.

35. Sörensdotter R, Siwe K. Touching the private parts: how gender and sexuality norms affect medical students' first pelvic examination. Cult Health Sex. 2016;18(11):1295-308.

36. Abraham S, Chapman M, Taylor A, McBride A, Boyd C. Anxiety and feelings of medical students conducting their first gynecological examination. J Psychosom Obstet Gynecol. 2003;24(1):39-44 https://doi.org/10.3109/01674 820309042799.

37. Dabson AM, Magin PJ, Heading G, Pond D. Medical students' experiences learning intimate physical examination skills: a qualitative study. BMC Med Educ. 2015;24:39 https://doi.org/10.1186/1472-6920-14-39.

38. Howley LD, Dickerson K. Medical students' first male urogenital examination: investigating the effects of instruction and gender on anxiety. Med Educ Online. 2003:8(1):436-40 https://doi.org/10.3402/meo.v8i.4336.

39. Siwe K, Berterö C, Wijma B. Unexpected enlightening of a "female world". Male medical students' experiences of learning and performing the first pelvic examination. Sex Reprod Healthc. 2012;3:123-7. 
40. Siwe K, Wijma B, Sile'n C, Berterö C. Performing the first pelvic examination: female medical students' transition to examiners. Patient Educ Couns. 2007; 69:55-62.

41. Clapper TC. Beyond Knowles: what those conducting simulation learning need to know about adult learning theory. Clin Simul Nurs. 2010;6(1):e7-e14.

42. Ende J. Feedback in clinical medical education. JAMA. 1983:350:777-81.

43. Taylor DCM, Hamady H. Adult learning theories: implications for learning and teaching in medical education: AMEE guide no. 83. Med Teach. 2013; 35(11):e1561-72.

44. Sadler DR. Formative assessment and the design of instructional systems. Instr Sci. 1989:18(2):119-44.

45. Nicol DJ, Macfarlane-Dick D. Formative assessment and self-regulated learning: a model and seven principles of good feedback practice. Stud High Educ. 2006;2:199-218 https://doi.org/10.1080/03075070600572090.

46. Godkins TR, Duffy D, Greenwood J, Stanhope WD. Utilization of simulated patients to teach the 'routine' pelvic examination. J Med Educ. 1974;49: 1174-8.

47. Johnson GH, Brown TC, Stenchever MA, Gabert HA, Poulson AM, Warenski JC. Teaching pelvic examination to second-year medical students using programmed patients. Am J Obstet Gynecol. 1975;121(5):714-7.

48. Women' Community Health Center. Inc: experiences of a pelvic teaching group. Women Health. 1975;1(4):19-20.

49. Hale RW, Schiner W. Professional patients: an improved method of teaching breast and pelvic examination. J Reprod Med. 1977;19(3):163-6.

50. Nelson LH. Use of professional patients in teaching pelvic examinations. Obstet Gynecol. 1978;52(5):630-3.

51. Wheeler LA, Burke MM, Ling FW. Nurse-midwife involvement in medical education: the pelvic examination. J Nurse Midwifery. 1981;26(1):34-7.

52. Laube DW, Kretzschmar RM, Guenther SM, Lessner JE, Guthrie D. A clinical skills instruction program: the acute abdomen. J Med Educ. 1982;57:726-8.

53. Fang WL, Hillard PJA, Lindsay RW, Underwood PB. Evaluation of students' clinical and communication skills in performing a gynecologic examination. J Med Educ. 1984;59:758-60.

54. Beckmann CRB, Sharf BF, Barzansky BM, Spellacy WN. Student response to gynecologic teaching associates. Am J Obstet Gynecol. 1986;155:301-6.

55. Hillard PJ, Fang WL. Medical students' gynecologic examination skills: evaluation by gynecology teaching associates. J Reprod Med. 1986;31(6): 491-6.

56. Beckmann CRB, Barzansky BM, Sharf BF, Meyers K. Training gynaecological teaching associates. Med Educ. 1988;22:124-31.

57. Muggah HF, Stateson S. The gynecological teaching associates program Can Nurse. 1988;84(2):28-30.

58. Nieman LZ, Kelliher GJ, Sachdeva AK, Cohen D. Evaluation of parallel pelvic breast and male genital/rectal teaching programs. J Am Med Wom Assoc. 1994;49(3):73-7.

59. Sachdeva AK, Wolfson PJ, Blair PG, Gillum DR, Gracely EJ, Friedman M. Impact of a standardized patient intervention to teach breast and abdominal examination skills to third-year medical students at two institutions. Am J Surg. 1997:173:320-5.

60. Costanza ME, Luckman R, Quirk ME, Clemow L, White MJ, Stoddard AM. The effectiveness of using standardized patients to improve community physician skills in mammography counseling and clinical breast exam. Prev Med. 1999; 29:241-9.

61. Legro RS, Gnatuk CL, Kunselman AR, Cain J. Oocyte donors as gynecologic teaching associates. Obstet Gynecol. 1999;93:147-50.

62. Hendrickx K, De Winter B, Wyndaele J, Tonks A. How medical students are being taught at the University of Antwerp. BMJ. 2003;326(7402):1327.

63. Carr SE, Carmody D. Outcomes of teaching medical students core skills in women's health: the pelvic examination educational program. Am J Obstet Gynecol. 2004;190:1382-7.

64. Coleman EA, Stewart CB, Wilson S, Cantrell MJ, O'Sullivan P, Carthron DO, et al. An evaluation of standardized patients in improving clinical breast examination for military women. Cancer Nurs. 2004;27(6):474-82.

65. Siwe K, Wijma K, Stjernquist M, Wijma B. Medical students learning the pelvic examination: comparison of outcome in terms of skills between a professional patient and a clinical patient model. Patient Educ Couns. 2007; 68:211-7.

66. Boendermaker PM, Faber V, Weijmar Schultz CM. Dealing with difficult sexual questions during consultations: a new training program. J Psychosom Obstet Gynecol. 2008;29(2):79-82.
67. Bokken L, Linssen T, Scherpbier A, van der Vleuten C, Rethans J. Feedback by simulated patients in undergraduate medical education: a systematic review of the literature. Med Educ. 2009;43:202-10.

68. Jha V, Setna Z, El-Hity A, Quinton ND, Roberts TE. Patient involvement in teaching and assessing intimate examination skills: a systematic review. Med Educ. 2010;44:347-57.

69. Pradhan A, Ebert G, Brug P, Swee D, Ananth CV. Evaluating pelvic examination training: does faculty involvement make a difference? A randomized controlled trial. Teach Learn Med Int J. 2010;22(4):293-7.

70. Siebeck M, Schwald B, Frey C, Röding S, Stegmann K, Fischer F. Teaching the rectal examination with simulations: effects on knowledge acquisition and inhibition. Med Educ. 2011;45:1025-31.

71. Seago BL, Ketchum JM, Willett RM. Pelvic examination skills training with genital teaching associates and a pelvic simulator: does sequence matter? Simul Healthc. 2012;7:95-101.

72. Grankvist O, Olofsson AD, Isaksson R. Can physicians be replaced with gynecological teaching women to train medical students in their first pelvic examination? A pilot study from northern Sweden. Patient Educ Couns. 2014;96:50-4.

73. Janjua A, Smith P, Chu J, Raut, Malick S, Gallos I, et al. The effectiveness of gynaecology teaching associates in teaching pelvic examination to medical students: a randomised controlled trial. Eur J Obstet Gynecol Reprod Biol. 2017;210:58-63.

74. Park CS, Murphy TF, the Code of Ethics Working Group: Healthcare Simulationist code of ethics. 2018 Available from: http://www.ssih.org/codeof-ethics.

75. Association of American Medical Colleges: Implementing curricular and institutional climate changes to improve health care for individuals who are LGBT, gender nonconforming, or born with DSD: a resources for medical educators. 2014. Available from: http://www.aamc.org/publications.

\section{Publisher's Note}

Springer Nature remains neutral with regard to jurisdictional claims in published maps and institutional affiliations.

Ready to submit your research? Choose BMC and benefit from

- fast, convenient online submission

- thorough peer review by experienced researchers in your field

- rapid publication on acceptance

- support for research data, including large and complex data types

- gold Open Access which fosters wider collaboration and increased citations

- maximum visibility for your research: over $100 \mathrm{M}$ website views per year

At $\mathrm{BMC}$, research is always in progress.

Learn more biomedcentral.com/submissions 